(November I8), seems, however, to indicate that the morning of the $15^{\text {th }}$ was far richer in meteors, as the following extract indicates: "At that hour (Sunday, 3 a.m.), however, we looked out, and finding that a few stars were 'on the shoot,' began to watch for them. Till well after four o'clock there were not many visible; something like one every two or three minutes. By five o'clock they markedly increased, and from 5.I 5 to 5.45 there was quite a shower, and between these times we counted over sixty meteors. Once three 'came away' almost simultaneously, and another time two flashed out together. Nearly all of them were very small, and had very short and very swift flight, and many were scarcely more than just visible. There was one brilliant exception that shot out from the feet of the Twins, and disappeared near Orion's belt, that was of first magnitude, and left a red streak that remained for twelve or fifteen seconds afterwards. At six o'clock the meteors seemed almost suddenly to cease, and shortly afterwards our vigil came to an end."

M. Perrotin, director of M. Bischoffsheim's private observatory at Nice, has resigned his post in order to become an observer at the Meudon Astro-physical Observatory.

\section{MR. BALFOUR ON SCIENCE AND INDUSTRY.}

$\mathrm{M}$ R. ARTHUR BALFOUR was the principal guest at the Cutlers' Feast at Sheffield last Thursday evening. In the course of his reply to the toast "Her Majesty's Ministers" he referred to scientific education 'in Germany, and the relations between science and manufacture. It is satisfactory to know that these subjects are now occupying the minds of our political leaders, and that such sound views should be expressed on the value of scientific research, and the true meaning of technical education, as those contained in the subjoined Times' report of Mr. Balfour's speech :-

"I think that, though we have not much to fear from the action of other nations, we have much to learn from the action of other nations. I have already said that I think John Bull requires the occasional stimulus of a panic to make him do his best. $\mathrm{He}$ is like a noble horse dragging a load, well within his weight, who perhaps gets a little slow in his action unless occasionally he hears the crack of the whip. I think that, though I do not envy the growth of German manufactures-taking Germany for example-though I neither envy the growth of German manufactures, nor fear the growth of German manufactures, though I do not think that German prosperity can be other than in the long run a help to British prosperity, still I am not so blind as to think, with regard to a nation which gives itself over with such fervour to everything which can by discipline and education promote its material prosperity, that we have nothing to learn by the study of its proceedings. I believe we have a good deal to learn, and I think it behoves us to learn it. Lord Rnsebery desired that an inquiry should be made into the topics on which I am venturing to arrest your attention to-night. That inquiry is being made, or is partly being made, by the department of the Government concerned. I do not profess to give the results of these inquiries, but it is an undoubted fact that the Germans do think it, rigatly or wrongly, to be worth while to spend money Imperially, municipally, and privately upon those branches of scientific research which have a direct bearing upon manufactures to an extent and degree absolutely unknown in this country, which surely ought to take the lead in all commercial matters. I have been informed by a gentleman who has recently come from an examination of these technical institutions in Germany that there are at this moment in Germany no fewer than six great technical institutions for the study of electrical matters alone, which are superior to anything of the kind which we have in this country. The witness of whom I speak was not a prejucliced witness. He went to Germany with no preconceived views either for or against the method of technical instruction there pursued, and I have faithfully detailed to you the information I gained. I am further informed, on evidence the value of which I cannot for a moment doubt, that, while the Government and the municipalities spend these vast sums in producing a great body of trained experts, the great manufacturers in Germany, to an extent altogether unknown in this country, employ a large body of investigators on their own account on their own premises, taking advantage of every discovery that can be made, and in so far as may be make discoveries for themselves. I do not comment upon the fact ; I simply state the fact to you. I should be reluctant to say how great is the advantage which any country thus liberally disposed is likely to reap. It may be that the Germans have been squandering their money in unremunerative investigation, and that they will not get in the shape of national profit any result for what they have done. That may be so, but I remember the late Mr. Bagehot's pointing out that one of the great advantages that England had over every other nation in the world was this-that when any discovery was made, when any new outlet of industry was invented, the amount of disposable English capital was so great that England reaped the chief benefit from it. Now this is the question I want to put. Is not Germany, by bringing into existence this vast body of fine specialists, preparing itself to make the utmost use of any possible advances in scientific manufactures which may be made? Is it not likely that it will have the advantage, as compared with other nations, in turning to account the smallest hint in any direction, in developing any discovery however slight, in making the most of any advance, however small that advance may be? That question I put to men incomparably more qualified to answer it than I am myself."

"But I think the question is worth putting in the great manufacturing centres of this country, and I would ask them not to be put off-I do not think Sheffield is likely to be put offbut I will ack any who read my words not to be put off with the idea that what is called technical instruction, by which I mean manual instruction in arts and crafts, however good in itself, has anything to do with the particular kind of education of which I am speaking. It has nothing to do with it, Education in the first three standards of your primary schools has more to do with the higher University training than the manual education of which I speak has to do with the technical education which I desire for the country. For the education in your primary schools is, after all, a necessary preliminary of your University education. You must learn to read, you must learn to write, you must learn to do arithmetic before you can take advantage of what Oxford and Cambridge, Edinburgh and Glasgow, have to give you, but still education in the three $R^{\prime}$ 's leads up to all this knowledge, but the manual education called technical does not lead up to and has no relation to or connection whatever with that scientific education of which I speak. England became a great manufacturing country, the greatest manufacturing country which the world has ever seen, before the intimate relation of organised science to manufactures was thoroughly understood. I fear that in some quarters it may still be a fact that the relation between science and manufactures is not thoroughly grasped, and there may still be some who think that money spent in what appears to be abstract investigations far removed from the practical things of life has but a small effect on national well-being and national commerce. If any hold that view, believe me, they are profoundly mistaken. They have not followed the course of human knowledge, they have not kept abreast of human progress, and if we have leeway to make up in this matter, if we have to learn a lesson which perhaps came easier to the Germans than it did to us, let us hasten, at all events, to learn that lesson completely, and then I doubt not we shall-even in the eyes of the most pessimistic critic-continue to hold that position which hitherto we have held unchallenged, and then British manufactures, British industry, British capital may still maintain throughout the world the supremacy they have so long held and so well deserved."

\section{THE LONG PERTOD WEATHER FORECASTS} $O F$ INDIA.

I $\mathrm{N}$ days when the cui bono of everything connected with scientific research is subjected to the glare of criticism by a public which is frequently too busy to analyse or understand the laborious methods by which accurate knowledge is attained, the Meteorological Service of India poses as a happy exception to that of many other scientific departments in being able to demon. strate its practical utility by the success, not merely of its everyday routine forecasts, but by its unique initiation and develop. ment of seasonal or long-period forecasts of the alternate monsoons.

The foundations so carefully laid by the late Mr. Blanford, have enabled his successor, Mr. Eliot, to realise the expectations he so hopefully expressed years ago regarding the important róle that India would play in the future development of meteorology. 